\title{
Effect of the temperature on the performance of a sludge activated petrochemical wastewater treatment plant
}

\author{
S. A. Martínez ${ }^{1}$, M. Morales ${ }^{2}$, M. Rodríguez ${ }^{1}$, R. Aguilar $^{1}$ \\ \& D. Narváez ${ }^{2}$ \\ ${ }^{1}$ Universidad Autónoma Metropolitana-Azcapotzalco, México \\ ${ }^{2}$ Petroquímica Morelos S.A. de C. V., México
}

\begin{abstract}
Petrochemical Morelos is located in an industrial zone among 50 refineries and petrochemical industries, in the coastal region of Mexico. All these industries produce $111 \mathrm{Mm}^{3} / \mathrm{d}$ of wastewaters which are discharged into the Coatzacoalcos River, previous treatment in their wastewater plants. However, the high temperatures in the region negatively affect the performance of the different wastewater plants increasing the discharge of pollutants into the river during the high temperatures in the year. Petrochemical Morelos has an activated sludge system to treat its wastewater flow which is about $7000 \mathrm{~m}^{3} / \mathrm{d}$. The aeration is supplied by a fine bubble diffusers system. Four compressors supply the air to the bioreactors. The high temperatures in the region and the compression effect on the air supply cause the temperature of the air exiting from the compressor to reach up to $82^{\circ} \mathrm{C}$. As a direct consequence of the high air temperature, the temperature in the bioreactor reaches $32^{\circ} \mathrm{C}$ during the fall, whereas in the spring and summer, the bioreactor temperature reaches up to $41^{\circ} \mathrm{C}$. The high temperatures have an adverse effect on the microbial activity and affect the performance of the biological process. In this study, the effect of temperature on the process is considered. A dynamic model, based on actual operation data, was validated at five scenarios presented during the year. The effect of temperature on $\mu_{\max }, k l a$ and $k d$, was incorporated in the mass balance equations of the model. Moreover, the model is applied to find the operating space of the process at different scenarios with the high temperatures, to reach the effluent quality standards required by Mexican environmental laws.
\end{abstract}

Keywords: activated sludge, modelling, petrochemical, wastewater, temperature. 


\section{Introduction}

Petrochemical Morelos is located in an industrial zone among 50 refineries and petrochemical industries, in the coastal region of Mexico. All these industries produce $111 \mathrm{Mm}^{3} / \mathrm{d}$ of wastewaters which are discharged into the Coatzacoalcos River, which in this part is an estuary, previous treatment in their wastewater plants. However, the high temperatures in the region affect negatively the performance of the different wastewater plants increasing the discharge of pollutants into the river during the high temperatures in the year. The Mexican petrochemical industry, Morelos S.A. de C.V., produces wastewater generated from the different chemical processes. The wastewater flow produced is about $7000 \mathrm{~m}^{3} / \mathrm{d}$ and contains volatile organic carbon substances classified as toxics as 1,2 dichloroethane, chloroform and benzene, among others volatile compounds (VOC's). To comply with the effluent quality required by the Mexican environment legislation, SEMARNAP [4], Morelos petrochemical remove the different pollutants the wastewater in a treatment plant before being discharged into the Coatzacoalcos River. The treatment plant is located near the Mexican coast, where the mean weather temperature in the hottest months (April to August) is nearly $35^{\circ} \mathrm{C}$ and it can reach up to $38^{\circ} \mathrm{C}$ at extreme conditions. Such high temperatures affect the air temperature at the compressor exit producing a significant air temperature rise up to $82^{\circ} \mathrm{C}$ or more. When the air enters through the diffusers, it provokes an increase of the temperature within the bioreactor liquor. As a matter of fact, the actual temperature conditions within the bioreactor are $32^{\circ} \mathrm{C}$ in October-November reaching up to $41^{\circ} \mathrm{C}$ in AugustSeptember. Due to high temperature effect, the microorganism's activity is affected; hence temperature plays an important role in the performance of the biological system that must be considered in the dynamic modelling of the process. Some models have been developed to describe the effect of temperature on bacterial growth, Heitzer et al. [3], Raltowsky et al. [6], and Zwietering et al. [9]. The authors showed that at high temperatures the maximum specific growth rate $\left(\mu_{\max }\right)$ is reduced.

The purpose of this study was to show to the other industries that discharge wastewaters, that it is possible to reduce the temperature effect on the wastewater treatment process to reduce de pollutants discharge to the estuary in this region of the Coatzacoalcos River, in order to preserve it, because is an important fishing zone for the inhabitants of the region. It was modelled the COD behaviour in the sludge activated treatment plant of the petrochemical at the different temperatures .in the region The temperature effect at the maximum specific growth rate, mass transfer coefficient for oxygen $(k l a)$ and death coefficient $\left(k_{d}\right)$, were incorporated in the mass balance equations of the process.

\section{Methods}

Experimental data were obtained from the petrochemical biological wastewater plant. Different samples were taken out daily (after 8 hours), from the influent wastewater and the bioreactors during the period from October 2002 to 
September 2003. The bioreactors capacity was $5000 \mathrm{~m}^{3}$ each. The flow was about $2300 \mathrm{~m}^{3} / \mathrm{d}$ to $2600 \mathrm{~m}^{3} / \mathrm{d}$ and the mean residence time in each bioreactor was about 2.0 days. The bioreactors operate with the bubble fine diffusers equipment (BFD). The power level in the chambers with the FBD system is about $0.04 \mathrm{HP} / \mathrm{m}^{3}$. It was considered that all the bioreactors were mixed flow reactors. The chemical oxygen demand (COD), biomass and dissolved oxygen were measured, APHA [8], in the plant's laboratory. Temperature and dissolved oxygen (DO) in the bioreactors were measured in situ. The mean of three replicates analyses was taken as the daily mean analysis per chamber. In order to obtain the results reported in the figures, the average of the daily mean analysis was obtained. The kinetic parameters were obtained in laboratory bioreactors following the method by Ramalho [7]. The eqns (7), (8) and (9) were used to evaluate the temperature effect on following parameters:

the maximum specific growth rate, was evaluated with eqn (7),

Ratkowsky et al. [6], where $\mathrm{b}=0.05 \mathrm{~K}^{-1} \mathrm{~h}^{-0.5}$, Heitzer et al. [3], and $\mathrm{c}=0.005$

$\mathrm{K}^{-1}$ (which is a parameter to fit the experimental data to the model), the death coefficient $\left(k_{d}\right)$ with eqn (8), Ramalho [7].

the mass transfer coefficient for the oxygen (kla) with eqn (9)

Eckenfelder [2].

All of these were incorporated in the mass balance equations of the process.

The activated sludge petrochemical wastewater treatment process is shown in figure 1.

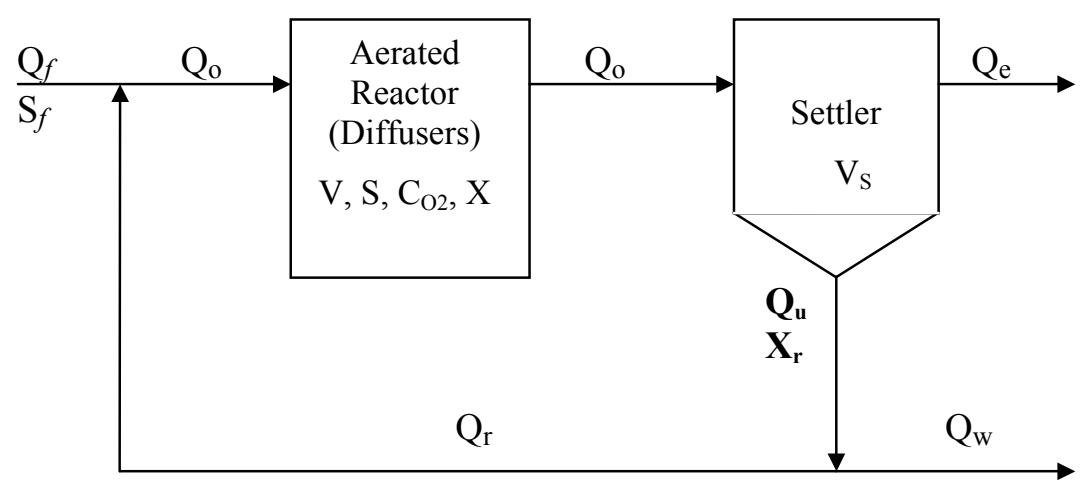

Figure 1: The activated sludge petrochemical wastewater treatment plant.

The process is described by the following mass balance equations, Olsson and Newell [5], and the temperature effect on different parameters is considered. The bioreactor behaviour was assumed as completely mixed flow reactor.

In the reactor the balance eqns (1), (2), (3) are as follows:

$$
\frac{d S}{d t}=\frac{Q_{f}}{V} S_{f}-\frac{Q_{O}}{V} S-\frac{\mu \max }{Y}\left(\frac{S}{K_{s}+S}\right)\left(\frac{C_{O_{2}}}{K_{O H}+C_{O_{2}}}\right) X+k_{d}\left(1-f_{n}\right) X
$$


174 Waste Management and the Environment III

$$
\begin{gathered}
\frac{d X}{d t}=\frac{Q_{r}}{V} X_{r}-\frac{Q_{O}}{V} X+\mu_{\max }\left(\frac{S}{K_{s}+S}\right)\left(\frac{C_{O_{2}}}{K_{\mathrm{OH}}+C_{O_{2}}}\right) X-k_{d} X \\
\frac{d O_{O_{2}}}{d t}=\frac{Q_{f}}{V} C_{O_{2 f}}-\frac{Q_{O}}{V} C_{O_{2}}-\frac{\mu_{\max }}{Y_{O_{2}}}\left(\frac{S}{K_{s}+S}\right)\left(\frac{C_{O_{2}}}{K_{O H}+C_{O_{2}}}\right) X+k l a\left(C_{O_{2 s a t}}-C_{O_{2}}\right)(3)
\end{gathered}
$$

It was assumed that there was no biomass at the overflow of the settler Dochain and Vanrolleghem [1].

In the settler eqns (4), (5), (6) are:

$$
\frac{d X_{r}}{d t}=\frac{Q_{U}}{V_{S}} X_{r}-\frac{Q_{O}}{V_{S}} X
$$

and

$$
\begin{gathered}
Q_{o}=Q_{f}+Q_{r} \\
Q_{U}=Q_{W}+Q_{r}
\end{gathered}
$$

where:

$\mathrm{t} \quad=$ time $(\mathrm{d})$

$\mathrm{Q}_{f}=$ influent flow rate $\left(\mathrm{m}^{3} / \mathrm{d}\right)$

$\mathrm{Q}_{r}=$ recycle flow rate $\left(\mathrm{m}^{3} / \mathrm{d}\right)$

$\mathrm{Q}_{W}=$ waste flow rate $\left(\mathrm{m}^{3} / \mathrm{d}\right)$

$\mathrm{S}_{f}=$ COD concentration in the influent $(\mathrm{mg} / \mathrm{L})$

$\mathrm{S}=\mathrm{COD}$ concentration in the reactor $(\mathrm{mg} / \mathrm{L})$

$\mathrm{X}=$ biomass concentration in the reactor $(\mathrm{mg} / \mathrm{L})$

$\mathrm{X}_{\mathrm{r}}=$ biomass concentration in the settler or volatile solids suspended in the settler (SSVS) (mg/L)

$\mathrm{C}_{\mathrm{O} 2 f}=$ dissolved oxygen concentration in the influent $(\mathrm{mg} / \mathrm{L})$

$\mathrm{C}_{\mathrm{O} 2}=$ dissolved oxygen concentration in the reactor $(\mathrm{mg} / \mathrm{L})$

$C_{O 2 \text { sat }}=$ dissolved oxygen saturation concentration $(\mathrm{mg} / \mathrm{L})$

$\mu_{\max }=$ maximum specific growth rate $\left(\mathrm{d}^{-1}\right)$

$$
\mu_{\max }=b^{2}(T w-285)^{2}\left(1-e^{[c(T w-330.5)]^{2}}\right) \cdot
$$

$\mathrm{b}=0.05\left(\mathrm{~K}^{-1} \mathrm{~h}^{-0.5}\right)$

$\mathrm{c}=0.005\left(\mathrm{~K}^{-1}\right)$

$\mathrm{Tw}=$ wastewater temperature in the reactor $\left({ }^{\circ} \mathrm{K}\right)$

$K_{s}=30 \mathrm{mg} / \mathrm{L}$ (substrate saturation coefficient)

$K_{O H}=0.2 \mathrm{mg} / \mathrm{L}$ (oxygen saturation coefficient)

$f_{n}=$ fraction inerts on decay $=0.1$ 
$k_{d}=$ death coefficient $\left(\mathrm{d}^{-1}\right)$

$$
k_{d}=k d_{20} 1.05^{\left(T_{w}-20\right)}
$$

$k_{d}=0.03\left(\mathrm{~d}^{-1}\right)=$ death coefficient at $20^{\circ} \mathrm{C}$

$\mathrm{Y}=0.67=$ yield coefficient $(\mathrm{mg}$ biomass produced $/ \mathrm{mg}$ COD consumed $)$

$\mathrm{Y}_{\mathrm{O} 2}=$ yield oxygen coefficient

$=2.03\left(\mathrm{mg}\right.$ biomass produced $/ \mathrm{mg} \mathrm{O}_{2}$ consumed $)$

$k l a=$ mass transfer coefficient $\left(\mathrm{d}^{-1}\right)$

$$
k l a=k l a \quad 201.02 \quad\left(T_{w}-20\right)
$$

$k l a_{20}=$ mass transfer coefficient at $20^{\circ} \mathrm{C}\left(\mathrm{d}^{-1}\right)$

$\mathrm{T}_{\mathrm{w}}=$ wastewater temperature in the reactor $\left({ }^{\circ} \mathrm{C}\right)$

$\mathrm{V}=15000 \mathrm{~m}^{3}$ (reactor volume)

$\mathrm{V}_{\mathrm{S}}=750 \mathrm{~m}^{3}$ (settler volume)

\section{Results and discussion}

The model was validated with the actual COD data obtained from the wastewater treatment plant during a year, from October 2002 to September 2003. Due to the different processes in the Morelos petrochemical, the atmospheric condition, the wastewater composition and operation; flow rates always were subject to variation along the year, five average operation scenarios were used to validate the model. Table 1 shows the different scenarios used to validate the dynamical modelling

Table 1: Scenarios presented during the wastewater treatment plant operation to validate the dynamical modelling

\begin{tabular}{|c|c|c|c|c|c|}
\hline Parameter & Scenario 1 & Scenario 2 & Scenario 3 & Scenario 4 & Scenario 5 \\
\hline $\mathrm{S}_{\mathrm{f}}(\mathrm{mg} / \mathrm{L})$ & 2500 & 2800 & 3100 & 2000 & 2600 \\
\hline $\mathrm{T}_{\mathrm{w}}\left({ }^{\circ} \mathrm{C}\right)$ & 32.5 & 38 & 36 & 39 & 41 \\
\hline $\mathrm{Q}_{\mathrm{f}}\left(\mathrm{m}^{3} / \mathrm{d}\right)$ & 7300 & 7200 & 7600 & 7300 & 7400 \\
\hline $\mathrm{Q}_{\mathrm{r}}\left(\mathrm{m}^{3} / \mathrm{d}\right)$ & 1500 & 2000 & 1500 & 2600 & 2600 \\
\hline $\mathrm{Q}_{\mathrm{w}}\left(\mathrm{m}^{3} / \mathrm{d}\right)$ & 950 & 700 & 800 & 800 & 750 \\
\hline
\end{tabular}

Due to the model is formed by four nonlinear differential eqns (1), (2), (3), (4), it was necessary to solved them with Runge-Kutta method.

In the Figure 2 it is shown that the model fits pretty well to the plant operation data trend during the different scenarios presented along one year operation of the wastewater petrochemical treatment plant. Based on this model, different 
estimations of COD in the bioreactor liquor were done at different operation conditions to find out the effect on the plant performance.

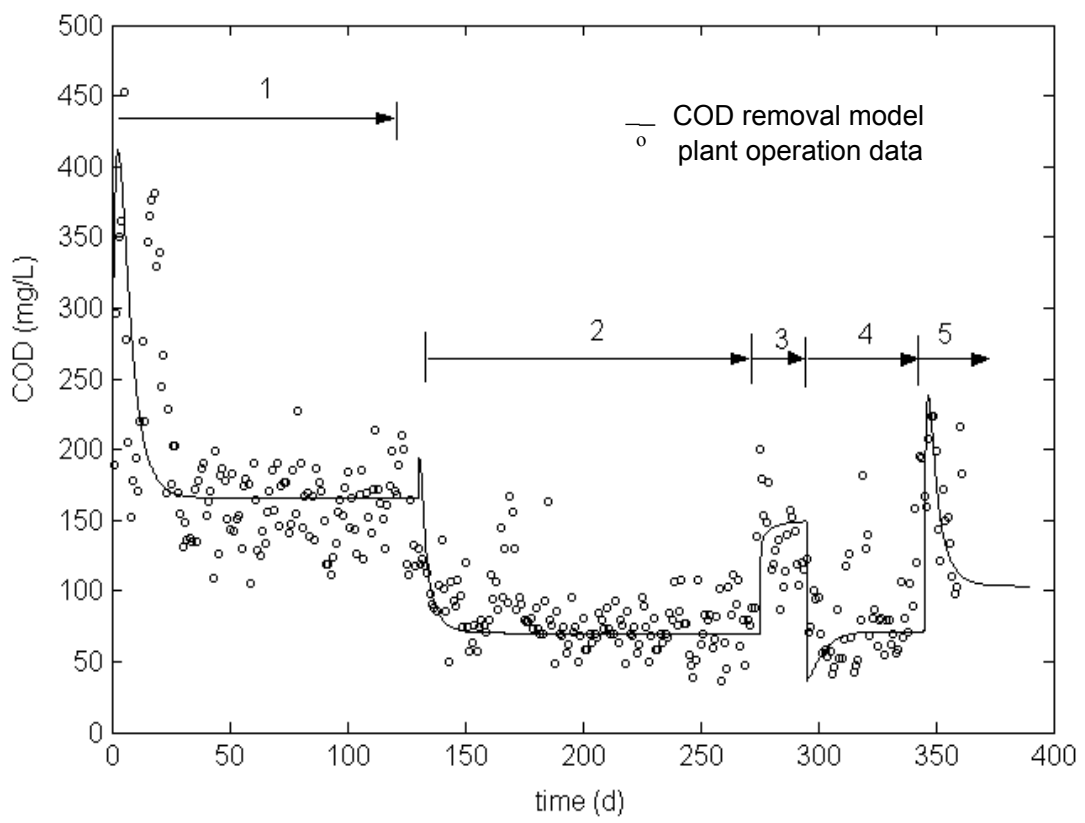

Figure 2: COD removal model and actual plant operation COD data presented along the year at the five different scenarios.

The temperature in the reactor, the recycle flow rate $\left(\mathrm{Q}_{r}\right)$ and the waste flow rate $\left(\mathrm{Q}_{W}\right)$ were changed to evaluate their effect on the COD removal. It is important to point out that both flows rates can be easily changed in plant to control the biological process, by this reason these were chosen.

Based on the model, different simulations were run in order to find out the behaviour of the system under different operation conditions and to control the adverse temperature effect driving off the system (i.e. changing the flow rates $\mathrm{Q}_{r}$ and $\mathrm{Q}_{W}$ ) to keep the COD concentration in the effluent at the permitted levels by the Mexican environmental regulations.

Figure 3 shows the COD in the bioreactor exit effluent when the wastewater treatment plant is operated at different $\mathrm{Q}_{r}, \mathrm{Q}_{W}$, and temperatures. As it can be seen, for the different $\mathrm{Q}_{r}$ and $\mathrm{Q}_{W}$, the COD in the effluent has the lowest values at temperatures between $32^{\circ} \mathrm{C}$ to $37^{\circ} \mathrm{C}$. This is because the microorganisms were acclimated to these conditions.

It is important to point out that at bioreactor temperatures lower than $30^{\circ} \mathrm{C}$ or higher than $37^{\circ} \mathrm{C}$, the activity of the biomass decreases as predicted by eqn (8).

The high COD concentration in the effluent exit from the bioreactors caused by the adverse effect of the extremes temperatures on the activity can be reduced 
by controlling the waste flow rate. The COD in the effluent is reduced as the $\mathrm{Q}_{W}$ become lower. In the same figure it is possible to see that the effect of the lower or higher temperatures on the activity of the microorganisms is reduced by the reduction of the $\mathrm{Q}_{W}$. This is because of the COD removal rate depends on the biomass concentration in the reactor $(\mathrm{X})$, which increases in the bioreactor, due to less quantity of biomass is taken out of the system.



Figure 3: COD bioreactor effluent at different operation temperatures, different $\mathrm{Qr}$ and $\mathrm{Q}_{\mathrm{w}}$.

The figure 4 shows the COD curves at different $Q_{r}\left(1800\right.$ to $\left.3000 \mathrm{~m}^{3} / \mathrm{d}\right)$, when the plant is operated at a constant $\mathrm{Q}_{w}=1000 \mathrm{~m}^{3} / \mathrm{d}$. If it is made a comparison at different $\mathrm{Q}_{r}$, it is observed that as the recycle flow rate increases, the temperature effect on the COD effluent is reduced. In case that the temperature increases at the highest levels (August to September), its effect on the process could be reduced by increasing the recycle flow rate.

Figure 5 shows the effect of different operation temperatures, $\mathrm{Q}_{r}$ and $\mathrm{Q}_{w}$, on the COD of the bioreactor's effluent, when the system is operated at $\mathrm{Q}_{w}(1000$ 
$\mathrm{m}^{3} / \mathrm{d}$ and $400 \mathrm{~m}^{3} / \mathrm{d}$ ), different temperatures and recycle flow rates. It is important to observe that at $\mathrm{Q}_{w}\left(1000 \mathrm{~m}^{3} / \mathrm{d}\right)$, more quantity of biomass is taken out from the bioreactor, hence the effect of the temperature on the COD removal is more important than if the system were operated at lower $Q_{w}\left(400 \mathrm{~m}^{3} / \mathrm{d}\right)$. On the one hand, the higher $\mathrm{Q}_{w}$, the smaller the range temperature is at which the COD in the effluent is less than $150 \mathrm{mg} / \mathrm{L}$, level permitted [4] by Mexican regulations, (e.g. from $29^{\circ} \mathrm{C}$ to $37^{\circ} \mathrm{C}$ at $\mathrm{Q}_{r}=3000 \mathrm{~m}^{3} / \mathrm{d}$ ), but on the other when the system is operated at $\mathrm{Q}_{w}=400 \mathrm{~m}^{3} / \mathrm{d}$, it is possible to operate the wastewater treatment plant in all the temperature range (from $25^{\circ} \mathrm{C}$ to $41^{\circ} \mathrm{C}$ ) and if it were operated at low $\mathrm{Q}_{r}$ the pumping costs would be reduced.

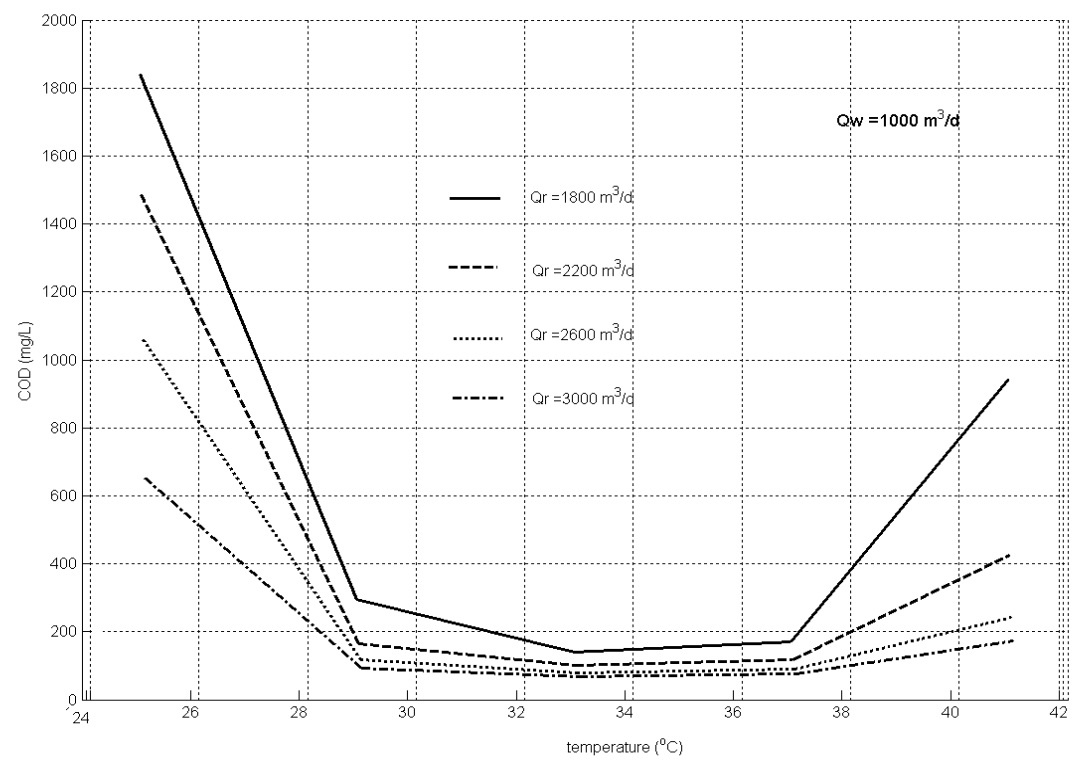

Figure 4: COD bioreactor effluent at different operation temperatures, $Q_{\mathbf{r}}$ and $\mathrm{Q}_{w}$.

It is important to point out that, as can be seen in figure 6 , as the waste flow rate is reduced, the volatile solids suspended in the settler (SSVS) increase. In the same figure, it is shown that, at lower waste flow rates $\left(\mathrm{Q}_{w}=400 \mathrm{~m}^{3} / \mathrm{d}\right)$, the SSVS concentrations reach higher values $(>17000 \mathrm{mg} / \mathrm{L})$, however at higher waste flow rates $\left(\mathrm{Q}_{w}=800 \mathrm{~m}^{3} / \mathrm{d}\right)$, the SSVS concentrations reach lower values $(<13000 \mathrm{mg} / \mathrm{L})$. The SSVS $\left(\mathrm{X}_{\mathrm{r}}\right)$ is very important parameters that must be considered because at high SSVS concentrations the height of the blanket sludge could be increased and this would cause the microorganisms go out in the overflow rate. In addition, as can be seen in the same figure, it is possible to control the high $\mathrm{X}_{\mathrm{r}}$ concentrations by changing the recycle flow rate. 


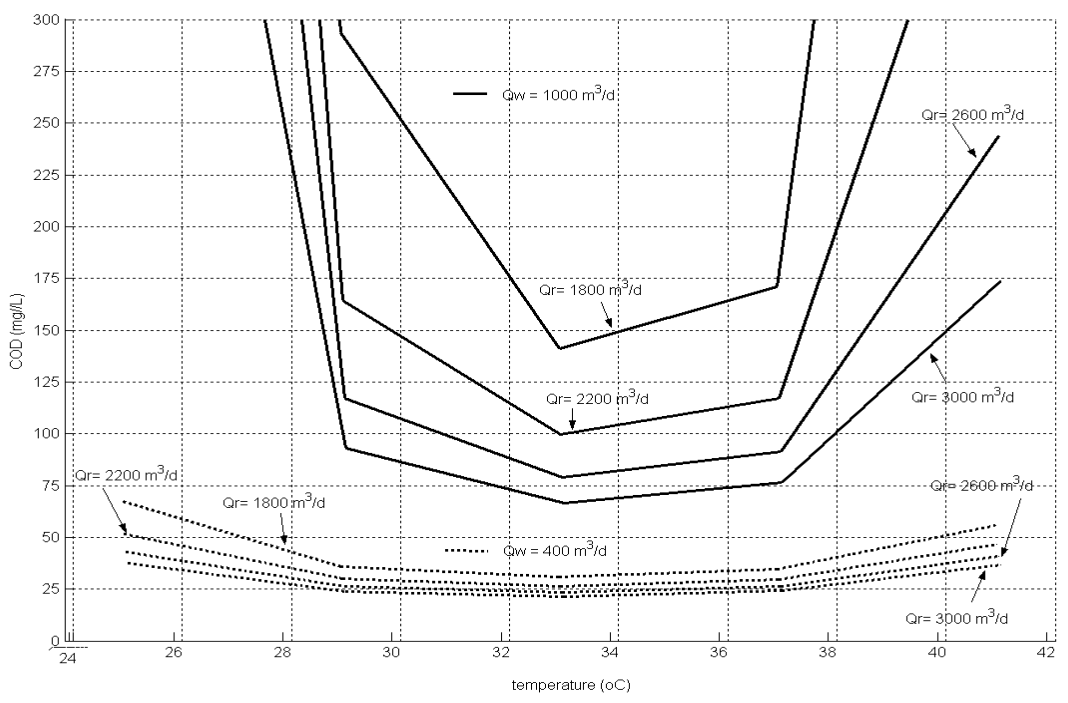

Figure 5: $\quad$ COD bioreactor effluent at different operation temperatures, $\mathrm{Q}_{r}$ and $\mathrm{Q}_{w}$.

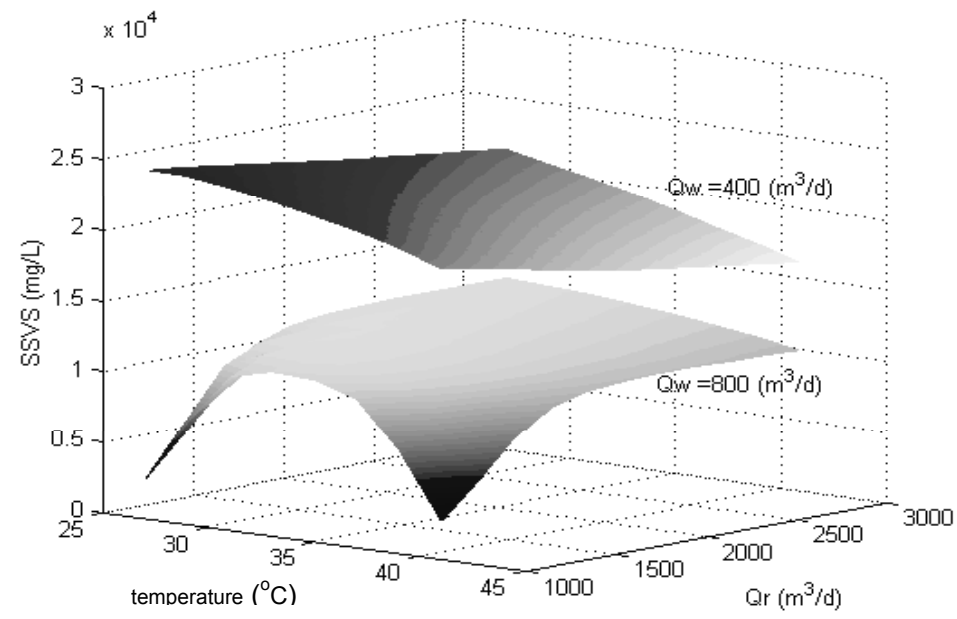

Figure 6: Volatile solids suspended in the settler (SSVS) at different temperatures and $\mathrm{Q}_{r}$ with $\mathrm{Q}_{w}=400 \mathrm{~m}^{3} / \mathrm{d}$ and $\mathrm{Q}_{w}=800 \mathrm{~m}^{3} / \mathrm{d}$.

The dissolved oxygen in the reactor also is affected by the changes in temperature, $\mathrm{Q}_{r}$ and $\mathrm{Q}_{w}$, however, after running the model, it was found that during all the scenarios presented along the year, the dissolved oxygen concentration in the bioreactor was $>2.5 \mathrm{mg} / \mathrm{L}$, this means that the aeration system is able to keep the dissolve oxygen concentration at adequate level during the operation of the petrochemical wastewater treatment plant. 


\section{Conclusions}

The performance of biological process depending on different temperatures and scenarios can be described by the dynamic model proposed in this work. The behaviour of the COD, biomass and oxygen in the reactor and also the biomass in the settler, can be known at different conditions. Moreover, based on the model, it is possible to find out the operating space of the biological wastewater treatment process to keep a good performance of the wastewater biological treatment process by means of the control of the recycle and waste flow rates.

This work could be used as an example to be done in other wastewater treatment plants of other industries in the region to reduce the discharge of pollutants to the estuary in this region of the Coatzacoalcos River, in order to preserve the aquatic life which is one of the most important sources of fishing in this region.

\section{Acknowledgements}

The authors wish to express their gratitude to Ing. Lorenzo Aldeco Ramírez, Subdirector de Operaciones de Pemex-Petroquímica, Ing. Guillermo García Reynaga, Auditor de Calidad, Seguridad y Protección Ambiental and Ing. Victor M. Herrero V., Subgerente de Calidad y Protección Ambiental, for the support given to conduct this study.

\section{References}

[1] Dochain, D. \& Vanrolleghem, P., Dynamic modeling and estimation in wastewater treatment process. IWA Publishing; U.K, 2001.

[2] Eckenfelder, W., Industrial water pollution control. Environmental. Engineering Series. McGraw Hill, 200).

[3] Heitzer, A., Hans-Peter E., Reichert, P. \& Hamer, G., Utility of phenomenological models for describing temperature dependence of bacterial growth. Appl. Environ. Microbiol., 57, pp. 2656-2665, 1991.

[4] NOM001-ECOL-1996, Ministry of the Environment, Natural Resources and Fisheries, SEMARNAP, México D.F., México, 1997.

[5] Olsson, G \& Newell, B., Wastewater treatment systems. Modelling, Diagnosis and Control, IWA Publishing: UK, 2001.

[6] Raltowsky, D.A., Ross, T., McMeekin, T.A. \& Olley, J., Comparison of Arrheius-type and Bélehrádek-type model for prediction of bacterial growth in foods. Journal of Appl. Bacteorology, 71, pp. 452-459, 1991.

[7] Ramalho, R. Wastewater Treatment, Reverté: Spain, 1999.

[8] Standard Methods for the Examination of Water and Wastewater 19th edn, APHA/AWWA/WEFederation, Washington DC, USA, 1995.

[9] Zwietering, M.H., De Koos, J.T., Hasenack, B.E., De Wit, J.C. and Van 'Triet, K., Modeling of bacterial growth as a function of temperature. Appl. Environ. Microbiol., 57, pp. 1094-1101, 1991. 